\title{
ОСОБЕННОСТИ РАЗВИТИЯ МАЛОГО И СРЕДНЕГО ПРЕДПРИНИМАТЕЛЬСТВА В РЕСПУБЛИКЕ ИНГУШЕТИЯ
}

\author{
(c) 2019 Магомадов Эмин Мухадинович \\ Чеченский государственный университет, Чеченская Респ., Грозный \\ E-mail: chgu@yandex.ru
}

В статье рассматриваются особенности развития малого и среднего предпринимательства в Республике Ингушетия, выявленные в результате анализа демографических тенденций организаций.

Предлагаются меры, способные при эффективной социально-экономической политике решить проблемы развития малого и среднего предпринимательства не только в Республике Ингушетия, но и улучшить экономический климат в целом по России.

Ключевые слова: малый и средний бизнес, демография организаций, тенденции развития.

Развитие малого и среднего предпринимательства - одна из актуальных проблем современной России. Особенно остро она проявляется в Республике Ингушетия.

Развитие малого и среднего предпринимательства в Республике Ингушетия должно стать одним из наиболее ярких проявлений взаимных интересов и взаимозависимости регионов Юга России. Это должно привести к увеличению объемов разнообразных хозяйственных связей и контактов между регионами.

Серьезные импульсы, стимулирующие углубление этих связей, создаются в результате становления процесса современной экономической интеграции. Стремление Республики Ингушетия использовать межрегиональную кооперацию для решения неотложных проблем своего социально-экономического развития стимулирует осуществление межрегионального хозяйственного сотрудничества.

По состоянию на 1 января 2014 г. в Российской Федерации зарегистрировано 5,6 млн. субъектов малого и среднего предпринимательства, на которых занято $25 \%$ от общей численности занятых в экономике.

В целом, если рассматривать демографию организаций, то в Республике Ингушетия в настоящее время коэффициенты рождаемости совпадают со средне российскими значениями.

Показатели официальной ликвидации организаций также сравнимы со средне российскими значениями. Как в Республике Ингушетия, так и в целом по России демография организаций характеризуется увеличением относительного количества ликвидаций и отсутствием роста рождаемости организаций в последние годы (см. рис).

Зарегистрированные и официально ликвидированные организации

в I полугодии 2018 года

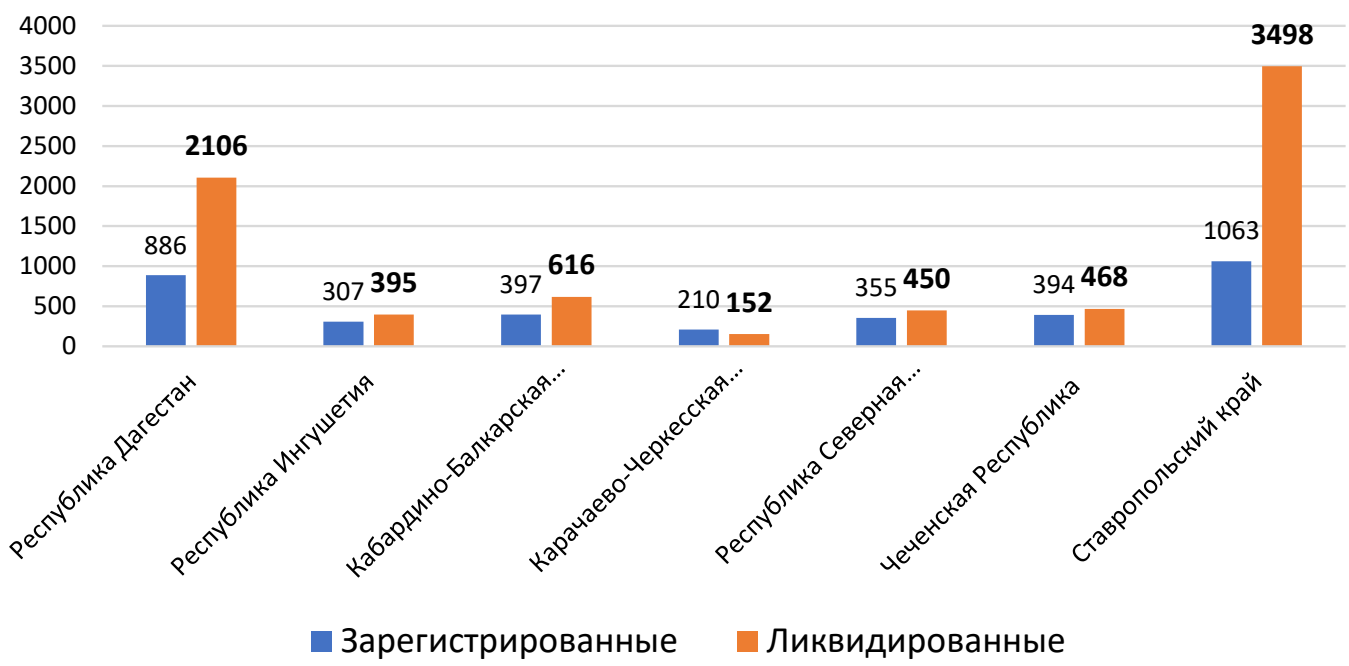

Рисунок. Соотношение числа зарегистрированных и официально ликвидированных организаций по субъектам СКФО в первом полугодии 2018 года 
В последнее время во многих субъектах СКФО число ликвидированных организаций начинает превышать количество зарегистрированных. Больше всего в абсолютном выражении было ликвидировано организаций в Республике Дагестан и в Ставропольском крае - около 2100 и 3500 организаций соответственно. КарачаевоЧеркесская Республика является единственным регионом, где в первом полугодии 2018 года количество зарегистрированных предприятий превышает число официально ликвидированных. В Республике Ингушетия количество ликвидированных организаций не на много превысило число вновь зарегистрированных (395 против 307).

Анализ динамики численности предприятий малого и среднего предпринимательства за последние годы показывает неустойчивость тенденций - за короткий временной интервал численность микропредприятий, малых и средних предприятий изменялась разнонаправленно, рост их количества мог сменяться их стремительным снижением и наоборот.

Сравнивая тенденции численности средних предприятий в Республике Ингушетия со среднероссийскими значениями, видим, что относи- тельные изменения совпадали со среднероссийскими тенденциями (если так можно говорить при отсутствии данных по Республике Ингушетия за 2012-2014 годы и за 2016 год).

Тенденцию численности малых предприятий в Республике Ингушетия за последние годы нельзя считать устойчивой - их количество в некоторые годы менялось несколько раз в сторону увеличения или уменьшения. Общая тенденция, описываемая линейным трендом $\mathrm{y}=-0,571 \mathrm{x}+65,85$, говорит о среднем ежегодном снижении на $0,57 \%$ количества малых предприятий относительно их количества в 2010 году. Среднероссийские тенденции более устойчивые, колебания численности малых предприятий происходили в небольшом диапазоне - около от 1 до 6\% ежегодно относительно уровня 2010 года до 2015 года. Изменения численности малых предприятий в Республике Ингушетия и в среднем по России в 2015 и 2016 годах совпадают. В целом, в 2016 году относительно 2010 года количество малых предприятий сократилось как в Республике Ингушетия, так и в среднем по России - их количество составило $80 \%$ и $75 \%$ соответственно от базового уровня.

Таблица 1. Динамика численности малых и средних предприятий в Республике Ингушетия (на конец года)

\begin{tabular}{|l|c|c|c|c|c|c|c|}
\hline & 2010 & 2011 & 2012 & 2013 & 2014 & 2015 & 2016 \\
\hline Средние предприятия & 2 & 1 & - & - & - & 2 & - \\
\hline Малые предприятия & 73 & 67 & 54 & 55 & 60 & 77 & 59 \\
\hline Микропредприятия & 496 & 760 & 1253 & 2642 & 3580 & 2869 & 1415 \\
\hline
\end{tabular}

Таблица 2. Динамика численности средних предприятий в Республике Ингушетия и в целом по России (на конец года)

\begin{tabular}{|l|c|c|c|c|c|c|c|}
\hline & 2010 & 2011 & 2012 & 2013 & 2014 & 2015 & 2016 \\
\hline Российская Федерация & 25170 & 15945 & 13767 & 13684 & 13691 & 19278 & 13346 \\
\hline Республика Ингушетия & 2 & 1 & - & - & - & 2 & - \\
\hline
\end{tabular}

Таблица 3. Динамика численности малых предприятий в Республике Ингушетия и в целом по России (на конец года)

\begin{tabular}{|l|c|c|c|c|c|c|c|}
\hline & 2010 & 2011 & 2012 & 2013 & 2014 & 2015 & 2016 \\
\hline Российская Федерация & 229083 & 242677 & 243065 & 234537 & 235579 & 232369 & 172916 \\
\hline Республика Ингушетия & 73 & 67 & 54 & 55 & 60 & 77 & 59 \\
\hline
\end{tabular}

Таблица 4. Динамика численности микропредприятий в Республике Ингушетия и в целом по России (на конец года)

\begin{tabular}{|l|c|c|c|c|c|c|c|}
\hline & 2010 & 2011 & 2012 & 2013 & 2014 & 2015 & 2016 \\
\hline Российская Федерация & 1415186 & 1593755 & 1759973 & 1828589 & 1868201 & 1990003 & 2597646 \\
\hline Республика Ингушетия & 496 & 760 & 1253 & 2642 & 3580 & 2869 & 1415 \\
\hline
\end{tabular}


Развитие динамики численности микропредприятий в Республике Ингушетия кардинально отличается от тенденций численности средних и малых предприятий. Если общие модельные тенденции количества малых предприятий были отрицательными, то количество микропредприятий демонстрирует тенденцию к возрастанию - параметры линейного тренда $\mathrm{y}=332,2 \mathrm{x}+530.4$ говорят о среднем ежегодном возрастании на $332 \%$ относительно их количества в 2010 году. В то же время скачкообразное изменение приблизило количество микропредприятий в Республике Ингушетия в 2016 году до уровня - 1415 (против 496 в 2010 году). Общероссийские тенденции также говорят об устойчивом увеличении численности микропредприятий - линейный тренд $\mathrm{y}=15.356 \mathrm{x}+75.328$ показывает средний прирост около $15 \%$ ежегодно относительно уровня 2010 года.

Структура предприятий по количеству работников в Республике Ингушетия незначительно отличается от их структуры в среднем по России. Наибольшую долю предприятий в Республике Ингушетия и в среднем по России составляют микропредприятия - 96\% и 93\% соответственно. Средние предприятия в исследуемой структуре составляют около 1\% как в Республике Ингушетия, так и в России. Доля малых предприятий в Российской Федерации составляет $6 \%$ от общего количества МСП, а в Республике Ингушетия эта доля почти в два раза меньше среднероссийского показателя.

Анализ демографических тенденций организаций выявляет некоторые особенности развития малого и среднего предпринимательства в Республике Ингушетия:

1. В целом прилагаются заметные усилия по улучшению бизнес-климата в Республике Ингушетия - в отдельные годы можно наблюдать заметное увеличение численности предприятий, как микропредприятий, так и малых предприятий;
2. Меры развития малого и среднего предпринимательства в Республике Ингушетия пока не смогли достичь устойчивости в его развитии, не обрели системный характер. Это предположение можно обосновать сильными скачками в демографии организаций;

3. Совпадение демографических тенденций организаций Республики Ингушетия со среднероссийскими тенденциями в некоторые годы позволяет говорить, очевидно, о заметном воздействии глобальных факторов, связанных, вероятно, с нормативно-правовым, налоговым регулированием, а также с общеэкономическими тенденциями;

4. Динамика «естественного движения» организаций в Республике Ингушетия показывает общую тенденцию повышения «смертности» и снижения «рождаемости» организаций;

5. В силу объективных причин развитие микропредприятий должно стать драйвером общего роста деловой активности в Республике Ингушетия. Во-первых, именно микропредприятия составляют основную долю предприятий МПС. Во-вторых, открытие малого микропредприятия является (или должно быть) более доступным направлением развития бизнеса с точки зрения юридического оформления, объема привлекаемых ресурсов и т.д.;

6. Демография населения в Республике Ингушетия, которая кардинально отличается в лучшую сторону от среднероссийских тенденций, не влияет существенно на демографию организаций;

7. Структура населения Республики Ингушетия и демографические тенденции в целом, говорят о большом потенциале республики, способном при эффективной социально-экономической политике решить проблемы развития малого и среднего предпринимательства не только в Республике Ингушетия, но и улучшить экономический климат в целом по России.

\section{Библиографический список}

1. Официальный сайт общероссийской общественной организации малого и среднего предпринимательства «Опора России».-Режим доступа: http://opora.ru

2. Магомадов Э. М. Особенности развития малого и среднего предпринимательства в Чеченской Республике // Экономика и предпринимательство. 2019. № 2 (103). С. 463-467.

3. Ильясов P.Х. Демография организаций в Чеченской Республике: анализ тенденций // Вестник Чеченского государственного университета. 2018. -№ 3 (31).- С. 36-41.

4. Широков, Б.М. Малый бизнес. Финансовая среда предпринимательства / Б.М. Широков.- М.: Финансы и статистика, 2017.- 496 с. 
5. Малое и среднее предпринимательство в России. Федеральная служба государственной статистики. URL: http://www.gks.ru

6. Малое предпринимательство в России. 2008-2017.

7. Предпринимательское право. Портал правовой поддержки предпринимательской деятельности. URL: http://businesspravo.ru

8. Регионы России. Социально-экономические показатели. 2008-2017. 